\title{
Research on Academic Achievements of Three Domestic Petroleum Universities Based on PA Database from the Perspective of Language Service
}

\author{
Yali Liu \\ School of Foreign languages \\ Xi'an Shiyou University \\ Xi'an, Shaanxi Province, 710065, China
}

\begin{abstract}
As a sunrise industry, the language service industry has become the focus of domestic academic circles and translation circles in recent years. Petroleum Abstracts database literature resources provide broad and professional coverage for knowing the frontiers and dynamics of the petroleum industry in the world and for studying the petroleum industry dynamics. Based on the macro and micro level respectively, the total items and the categories published by the natural science edition of journal of three domestic petroleum universities included by PA database are analyzed. By comparing the three journals, the published specialty fields are summarized. Thus the reason for the different focuses is explored. The suggestion for the exchange of academic achievements and for the learning of academic frontiers is provided: establish a language service team on campus to facilitate the development of scientific research.
\end{abstract}

Keywords-language service; PA database; Academic achievements

\section{INTRODUCTION}

According to the BP2016 World Energy Outlook, fossil fuels will remain the dominant energy source to power the world economy by 2035 . At the same time, rapid technological innovation is driving the development of the oil and gas industry. High technology penetrating into oil and gas industry has promoted the petrochemical technology and petrochemical equipment level, accelerated the upgrading of petroleum and petrochemical products. High value-added, high-tech and environmental protection products have continuously emerged. Oil and gas exploration, refining and chemical industry and some other fields have made new development. Oil industry plays an irreplaceable role for economic and social development. Grasping the advanced achievements and studies timely is very important, which directly affects the progress and trend of the overall development of the domestic oil industry. In the globalization era, as domestic petroleum industry professionals acquire the advanced technologies and processes from the outside world or introduce them to the outside world in a timely manner or learn the development trend of the whole industry, it is inevitable that they need to accurately transform their scientific research results into language types that are easy for the target language readers to obtain. The differences of cultures and ways of thinking lead to the problem that whether the language expression is "authentic" or not, which will undoubtedly be related to whether the journals or periodicals will include the articles or not.

\section{GENERAL INTRODUCTION OF THREE JOURNALS}

Currently, China University of Petroleum (Beijing) edits and publishes four academic journals: Petroleum Science Bulletin, Petroleum Science, Journal of Paleogeography and Paleogeography. Therefore, the Journal of China University of Petroleum (Edition of Natural Science) included in PA database refers to China University of Petroleum (East China). In 1959, Journal of Beijing Petroleum Institute was founded. In 2005, the journal was renamed Journal of China University of Petroleum (natural science edition), which mainly features innovative achievements and high-level papers in the fields of geology and exploration engineering, drilling and production engineering, oil and gas storage and transportation and mechanical engineering, oil and gas chemical engineering, and the interdisciplinary basics and its applied researches.

In 1960, Journal of Southwest Petroleum Institute was founded. In 2008, the journal changed its name to Journal of Southwest Petroleum University (natural science edition), which mainly published the creative or innovative academic and technical papers in the oil industry and the basic theory researches. It mainly serves for the teachers of the Southwest Petroleum University to do the scientific research. It also publishes the scientific research achievements related to oil and gas exploration, reservoir engineering, drilling technology and equipment, oil and gas well completion and protection, oilfield chemistry and oilfield ground engineering, etc.

In 1959, Journal of Xi'an Shiyou Institute (natural science edition) was founded. In 2004, the journal changed its name as Journal of Xi' an Shiyou University (natural science edition). It sets with these columns: geology and exploration, oil drilling engineering, oil and gas field exploitation, processing and storage and transportation of oil and gas, chemical engineering, mechanical engineering, electrical engineering and its automation, oil machinery and equipment and its automation, computer and the application of new technologies, which is characterized by the geology and exploration, oil and gas field exploitation columns. It introduces the latest research results, new information and new methods researched by the petroleum majors in Xi'an Shiyou University and the professionals in the 
petroleum industry to the outside world timely. It serves the development of China's petroleum industry.

III. COMPARISON OF ACADEMIC DIFFERENCES AMONG THREE PETROLEUM UNIVERSITIES BASED ON PA DATABASE

\section{A. Introduction of PA and Its Inclusion Principle}

The Petroleum Abstracts database is an oil specialty database compiled and published by the Information Services Department (the University of Tulsa) in Oklahoma. Since its establishment in 1961, the articles contained in it have represented the highest level in petroleum exploration and processing research. It is an important retrieval tool for oil and natural gas majors. Resource types include journals, conference documents, patents, technical reports, government documents and reports, academic papers, books and maps. It has collected about 700 kinds of petroleum journals in 28 languages in the world (including major Chinese petroleum journals). All of them is recorded in English. The main contents are related to geology, geochemistry, geophysics, drilling, completion and maintenance, storage and transportation engineering and recycling method, pipe laying, transportation and storage, complementary technology, etc. Up to now, the database has provided more than 900,000 records since 1965. It updates weekly. PA has become a comprehensive and authoritative resource on exploration and development in the oil industry, through which we can learn the professional achievements and dynamics in the oil industry of various countries around the world.
The principle of this database inclusion is formulated by the editing department of the database. The editorial department will evaluate the journals related to the subject area of the database globally. If the journals conform to the standards, they will be officially included in the database. At this time, all articles in the journal will be included, rather than some being randomly selected. However, after a journal is included in the database, it may be excluded because it is not up to the inclusion standards and then be included again after a period of time (less often).

\section{B. Differences in academic achievements of three petroleum} universities included by PA database at the macro level

After retrieving the database through the journal name and truncation symbols, the results are shown in table 1 . The number of entries of the Journal of China University of Petroleum (Edition of Natural Science) in PA database from 2015 to 2017 is 175, 158 in the Journal of Southwest Petroleum University (Science \& Technology Edition) and 162 in Journal of Xi'an Shiyou University (Natural Science Edition). The included number of entries of the Journal of China University of Petroleum (Edition of Natural Science) is 17 more than that in the Journal of Southwest Petroleum University (Science \& Technology Edition), and 13 more than that in the Journal of Xi'an Shiyou University (Natural Science Edition).

TABLE I. DIFFERENCES IN ACADEMIC ACHIEVEMENTS OF THREE PETROLEUM UNIVERSITIES INCLUDED BY PA DATABASE AT THE MACRO LEVEL

\begin{tabular}{|c|c|c|c|}
\hline $\begin{array}{l}\text { Item } \\
\end{array}$ & $\begin{array}{c}\text { Journal of China University of } \\
\text { Petroleum (Edition of Natural Science) }\end{array}$ & $\begin{array}{c}\text { Journal of Southwest Petroleum } \\
\text { University (Science \& Technology } \\
\text { Edition) }\end{array}$ & $\begin{array}{c}\text { Journal of Xi’an Shiyou } \\
\text { University (Natural Science } \\
\text { Edition) } \\
\end{array}$ \\
\hline $\begin{array}{c}\text { Total number of entries in PA } \\
\text { database }\end{array}$ & 637 & 158 & 162 \\
\hline $\begin{array}{l}\text { The number of entries in PA } \\
\text { database from } 2015 \text { to } 2017\end{array}$ & 175 & 158 & 162 \\
\hline Publication time & 1959 & 1960 & 1959 \\
\hline ISSN & $1673-5005$ & $1674-5086$ & $1673-064 X$ \\
\hline $\mathrm{CN}$ & $37-1441 / \mathrm{TE}$ & 51-1718/TE & 61-1435/TE \\
\hline $\begin{array}{l}\text { (2018 edition) Composite impact } \\
\text { factor }\end{array}$ & 1.547 & 1.517 & 0.867 \\
\hline $\begin{array}{l}\text { (2018 edition) Comprehensive } \\
\text { impact factor }\end{array}$ & 1.265 & 1.119 & 0.602 \\
\hline Publication place & Shandong, Dongying & Sichuan, Chengdu & Shaanxi, Xi'an \\
\hline About the journal & $\begin{array}{c}\text { Core Journal } \\
\text { CA SA JST Pж (AJ) EI CSCD }\end{array}$ & $\begin{array}{c}\text { Core Journal } \\
\text { CA JST Pж (AJ) CSCD }\end{array}$ & $\begin{array}{l}\text { Core Journal } \\
\text { CA JST }\end{array}$ \\
\hline
\end{tabular}

C. Differences in academic achievements of three petroleum universities included by PA database from 2015 to 2017 at the micro-level

The PA database is classified as the following categories: alternate fuels \& energy sources, drilling(well), ecology \& pollution, geochemistry, geology, geophysics, mineral commodities, pipelining, shipping \& storage, production of oil \& gas, reservoir engineering \& recovery methods, supplemental technology, well completion \& servicing, well logging and surveying.

As can be seen from the statistical figure in table II, the achievements of the three universities in studying geology included in the PA database are significantly higher than those in other fields, which means that the journals publish more articles in the field of geology. The articles published in the field of geology in Southwest Petroleum University and Xi'an Shiyou University are almost even. In addition, each university has its own unique research field with remarkable results. In comparison, Journal of China University of Petroleum (Edition of Natural Science) has more achievements in drilling, geophysics, production of oil \& gas. Journal of Southwest Petroleum University (Science \& Technology Edition) includes more achievements in the field of reservoir engineering \& recovery methods than those of the other two. Journal of Xi'an Shiyou University (Natural Science Edition) has more articles 
in geochemistry than that of Journal of China University of Petroleum (Edition of Natural Science) and Journal of Southwest Petroleum University (Science \& Technology Edition). To some extent, this figure reflects the characteristics of the edition of the natural science of the three universities and their featured fields, as well as their innovative achievements for the development of the oil industry.

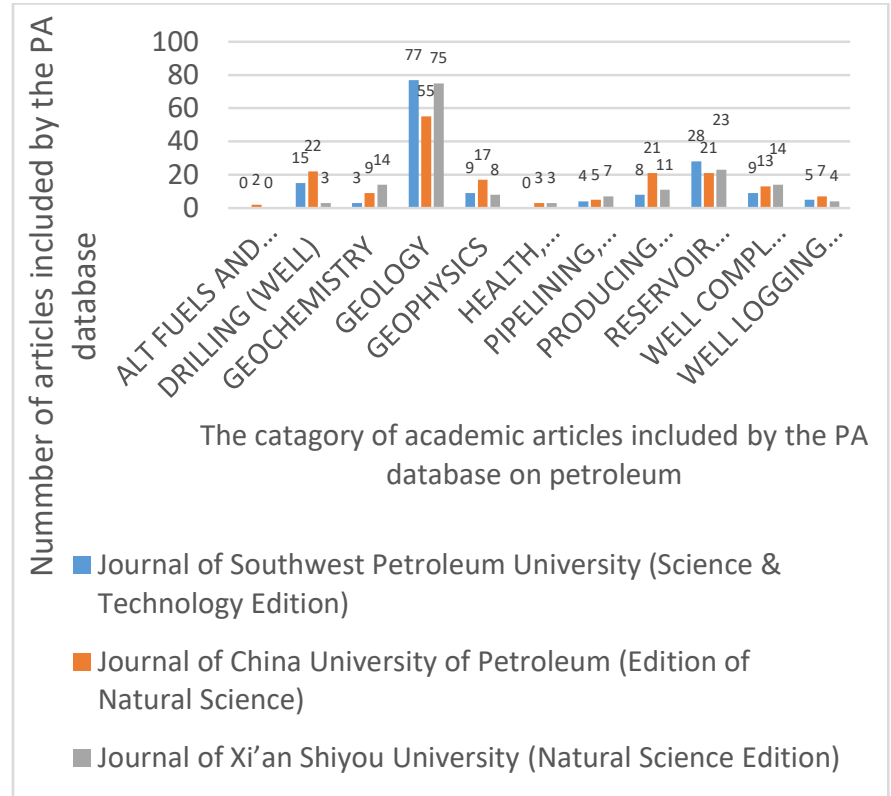

Fig. 1. Differences in academic achievements of the three journals included by PA database from 2015 to 2017 at the micro-level

\section{LANGUAGE SERVICE SERVES FOR CHARACTERISTIC DISCIPLINES IN UNIVERSITIES}

\section{A. Overview of the language service industry}

In 2010, the Translators Association of China first mentioned the concept of "language service industry" at the China international conference on language service industry. Language service industry provides the service of language, language knowledge, language technology and language derivatives to meet the needs of life and business, including translation, localization, language consulting, language training, multilingual information intelligence, language technology research and development and application and other services [8]. In a broad sense, language service covers the allocation, planning and continuous utilization of language resources, or the activities of taking language as content or product, which have political, economic and cultural values. In a narrow sense, language service refers to the extension and innovation of the translation service, including the content translation or form conversion of the texts, or commercial activities providing technologies and equipment required for the text conversion ${ }^{[2]}$. Common Sense Advisory, Inc., a leading business globalization research and consulting firm, launched its independent language service provider (LSP) certification program. According to the CSA report, the growing market for outsourced language services in 2018 exceeded $\$ 46.5$ billion. In the decade from 2009 to 2018, the language service industry as a whole maintained continuous growth, with a growth rate of 5.53 percent from 2016 to 2017 and 7.99 percent from 2017 to 2018.

As one of the emerging industries in China, language service industry started relatively late, but its development speed is amazing and, therefore, it is called the sunrise industry. Language service has penetrated into various traditional businesses in the global market. In recent years, the demand for language service and the cultivation of talents in this field have become the focus of domestic academic circles and translation circles, which has become increasingly prominent.

\section{B. Language service industry contributes to the development of academic achievements of characteristic disciplines}

There are four universities as MTI training units characterized by petroleum in China, namely China University of Petroleum (Beijing), China University of Petroleum (East China), Southwest Petroleum University and Xi'an Shiyou University [3]. According to the characteristic courses in the MTI curriculum of petroleum universities, Xi'an Shiyou University schedules one required course, 8 elective courses, while 2 compulsory courses and 6 elective courses related to petroleum are set up by China University of Petroleum (Beijing). 2 compulsory courses and 2 elective courses are included in China University of Petroleum (East China), while no compulsory course and 2 elective courses on petroleum are set up by Southwest Petroleum University.

From what has been discussed above, although Xi'an Shiyou University offers the largest number of specialized courses of petroleum for MTI majors in China, it has not built a language service team servicing for the publication of academic research achievements of the researchers.

Language is the foundation in the exchange process. In terms of domestic periodicals, it is necessary to refer the language as the carrier in the process of reflecting the Chinese scientific research achievements level. English is currently a universal language in the world, so academic journals with English as the carrier have advantages from the perspective of readers ${ }^{[6]}$. So, it is necessary to pay more attention to the language carrier factor as the domestic scientific research results are written in English and published on foreign journals. The acquisition of the latest foreign achievements is also inseparable from the language carrier.

In order to make researchers' academic achievements "go out" and learn the latest research trends of the industry, as well as to introduce high-quality manuscript articles to the outside so as to enhance the influence of the school journals, it is necessary to establish a language service team in the university to facilitate a better exchange of the scientific research achievements. In this process, students who are interested in the scientific research, especially MTI students who are committed to the scientific research, can participate in the language service team and, under the guidance of the tutor, make a modest contribution to the exchange of scientific research results of the school. At the same time, it is a powerful way to cultivate language service talents and it is also an effective way to combine the industry, education and research together and to facilitate a school's characteristic disciplines. If a language service team is set up in a university, it will 


\section{REFERENCES}

certainly do a lot of help for the school's characteristic disciplines and will contribute to the development of the school's academic achievements. Moreover, the campus language service team has many advantages over the social language service organizations, which will be a favorable supplement to the social language service organizations.

\section{CONCLUSION}

Language service team is not only needed in universities characterized by petroleum, but also in universities characterized by other subjects. Setting up a language service team on campus really matters. It is of great importance for the whole society, school and the individual students. Forming a language service team under the guidance of the tutor among the students who are a large research force in the university is a powerful way to train language service talents and an important way to combine industry, education and research effectively. At the same time, the language service team will also promote the accurate and timely acquisition of the academic results, and will contribute to the mastery of professional dynamics and subject frontiers.
[1] Q. L. Cui, C. Y. Wang, Research on the innovation and reform of MTI education model oriented to language service. Foreign Language Research, vol.7, pp. 8-15, 2019. (In Chinese)

[2] Q. L. Cui, Y. Zhang, Research on the basic problems of language service industry. Business Foreign Language Research, vol.1, pp. 1-8, 2016. (In Chinese)

[3] L. Chun, X. D. Wang, A brief analysis on the dilemma and countermeasures of MTI education in colleges with industry characteristics -- taking petroleum colleges as an example. Academic Degrees \& Graduate Education, vol.11, pp. 42-45, 2016. (In Chinese)

[4] H. Z. He, Introduction to the language industry, Beijing: capital normal university press, 2012. (In Chinese)

[5] S. J. Kang, From "language economics" to language industry -- on the countermeasures of the current situation and the development of China's language industry. Business economics research, vol.24, pp. 168-170, 2018. (In Chinese)

[6] L. H. Xu, X. S. Xiao, On the effective ways to enhance the international influence of Chinese academic journals. Social work and management, vol.19, pp. 101-106, 2019. (In Chinese)

[7] J. S. Yu, S. S. Geng, Research on training methods of practical language service talents -- a case study of "cross-border e-commerce web-page localization” competition. Foreign language electrochemical teaching, vol.1, pp. 84-89, 2019. (In Chinese)

[8] H. Y. Zhang, Chinese language service industry under the background of "the Belt and Road" Initiative: environmental analysis and countermeasures. Foreign language world, vol.1, pp. 84-89, 2018. (In Chinese) 